\title{
SITUASI KEBAHASAAN DI WILAYAH PANGANDARAN (TELAAH PERGESERAN DAN PEMERTAHANAN BAHASA)
}

\section{Eli Herlina}

\section{Pendidikan Bahasa dan Sastra Indonesia Universitas Wiralodra}

e-mail: eli.herlina@unwir.ac.id

\begin{abstract}
ABSTRAK
Bahasa adalah alat komunikasi yang hanya dimiliki manusia. Seiring perkembangan zaman, tidak menutup kemungkinan terjadi pergeseran bahasa.Pergeseran bahasa biasanya terjadi dalam komunitas bilingual atau multilingual yang disebabkan karena adanya kontak bahasa. Banyak faktor yang menyebabkan terjadinya pergeseran bahasa, antara lain pengaruh budaya global, migrasi, industrialisasi, perubahan ekonomi, urbanisasi, dan prestise. Oleh karena itu, peneliti tertarik untuk meneliti situasi kebahasan di wilayah wisata Pangandaran. Mengingat masyarakat Pangandaran adalah komunitas yang plural. Komunitas di Pangandaran tidak hanya didominasi oleh penduduk asli yang beretnis Sunda, tetapi juga para pendatang seperti dari Jawa, karena letak geografisnya yang berbatasan dengan wilayah Jawa Tengah. Selain itu, karena sebagian besar wilayahnya berupa pantai sehingga banyak para nelayan dari pulau lain yang datang dan menetap di Pangandaran.
\end{abstract}

\section{Kata Kunci: Situasi Kebahasaan, Pergeseran Bahasa, dan Pemertahanan Bahasa.}

PENDAHULUAN

Pentingnya bahasa kini semakin disadari oleh masyarakat di seluruh dunia. Hal ini terutama dipicu oleh kenyataan bahwa banyak bahasa di dunia, terutama bahasa ibu atau bahasa daerah, yang mengalami pergeseran dan bahkan keberadaannya terancam punah. Fenomena ini terjadi pula di Indonesia.

Perlu diingat bahwa pergeseran bahasa biasanya terjadi dalam komunitas bilingual atau multilingual yang disebabkan karena adanya kontak bahasa. Meski tidak setiap pergeseran bahasa mengarah pada musnahnya suatu bahasa dalam suatu komunitas, tetapi situasi kebahasaan di suatu wilayah perlu untuk dicermati agar kepunahan bahasa dapat dihindari. Faktor utama terjadinya kepunahan bahasa adalah adanya kontak bahasa.

Berdasarkan hal tersebut, peneliti tertarik untuk menelaah lebih jauh mengenai situasi kebahasaan di wilayah Pangandaran terutama yang berkenaan dengan kemungkinan adanya gejala pergeseran dan pemertahanan bahasa yang terjadi di sana. Komunitas di Pangandaran tidak hanya didominasi oleh penduduk asli yang beretnis Sunda, mengingat Pangandaran merupakan daerah tujuan pariwisata sehingga banyak pula turis asing yang berkunjung dan bahkan menikah dengan penduduk lokal serta menetap di sana. Masing-masing etnis tersebut memiliki bahasa masing-masing sehingga bahasa yang dipakai di sana pun menjadi beragam dan yang dominan dipakai adalah bahasa Sunda, Jawa, Indonesia, dan Inggris.

\section{KAJIAN PUSTAKA}

Suatu komunitas tutur yang mempunyai hubungan dengan komunitas tutur lain, maka akan terjadilah kontak bahasa. Oleh karena itu, besar kemungkinan banyak peristiwa kebahasaan yang akan terjadi. Salah satu peristiwa kebahasaan itu 
adalah bilingualisme atau dalam bahasa Indonesia dikenal dengan istilah kedwibahasaan.

Selain bilingualisme, dalam sosiolinguistik pun dikenal istilah multilingualisme. Pada intinya, konsep antara bilingualisme dan multilingualisme sama. Namun, multilingualisme berkenaan dengan keadaan digunakannya lebih dari dua bahasa oleh seorang penutur dengan orang lain ketika berkomunikasi secara bergantian (Chaer \& Agustina, 1995: 112).

Fasold (1984:180) mengemukakan hal pertama yang terbayang bila memikirkan bahasa adalah bahasa secara keseluruhan (whole language). Artinya yang terbayangkan adalah seseorang dalam masyarakat bilingual atau multilingual berbicara dengan menggunakan dua bahasa atau lebih dan harus memilih yang mana yang harus dipakai. Dalam pemilihan bahasa, terdapat tiga jenis pilihan: (1) dengan alih kode (code switching) yaitu menggunakan suatu bahasa pada suatu ranah dan menggunakan bahasa lain pada ranah yang lain; (2) dengan campur kode (code mixing) yaitu menggunakan satu bahasa tertentu dengan dicampuri serpihan-serpihan bahasa lain; dan (3) dengan menggunakan suatu variasi dalam satu bahasa (variation within the same language).

Menurut Fishman (dalam Chaer \& Agustina, 1995: 204) untuk mengkaji pemilihan bahasa dapat dilakukan dengan menggunakan konteks institutional tertentu yang disebut dengan domain atau ranah, yang di dalamnya menunjukkan kecenderungan menggunakan satu variasi tertentu daripada variasi lain. Domain atau ranah dipandang sebagai konstelasi faktorfaktor seperti lokasi, topik, dan partisipan (keluarga, tetangga, teman, atasan). Misalnya jika seorang penutur berbicara dalam lingkungan keluarga maka dikatakan berada dalam domain/ranah keluarga. Analisis domain ini biasanya terkait dengan analisis diglosia, sebab ada domain yang formal dan domain yang tidak formal. Di masyarakat yang diglosia untuk domain yang tidak formal dapat digunakan bahasa ragam rendah (low language), sedangkan dalam domain yang formal dipakai bahasa ragam tinggi (high language). Maka pemilihan satu bahasa atau ragam bahasa tergantung domain atau ranahnya.

Menurut Fasold (1984: 213-214) pergeseran dan pemertahanan bahasa merupakan hasil dari proses pemilihan bahasa dalam jangka waktu yang sangat panjang. Pergeseran bahasa menunjukkan adanya suatu bahasa yang benar-benar ditinggalkan oleh komunitas penuturnya. Hal ini berarti bahwa ketika pergeseran bahasa terjadi, anggota suatu komunitas bahasa secara kolektif lebih memilih menggunakan bahasa baru daripada bahasa lama yang secara tradisional biasa dipakai. Sebaliknya, dalam pemertahanan bahasa para penutur suatu komunitas bahasa secara kolektif memutuskan untuk terus menggunakan bahasa yang mereka miliki atau yang secara tradisional biasa digunakan.

Paparan di atas bukanlah satusatunya hal yang menjadi dasar dapat diprediksinya pergeseran dan pemertahanan bahasa. Hal terpenting justru seharusnya dapat diprediksi kapan suatu komunitas mulai berganti identitas. Prediksi semacam ini tampaknya tidaklah mungkin, setidaknya untuk saat ini. Akan tetapi, setidaknya terdapat sinyal-sinyal tertentu yang menunjukkan bahwa suatu komunitas sedang mengalami proses pergeseran bahasa pada waktu tertentu. Salah satunya, kecenderungan yang sering tampak dalam memertahankan perbedaan antara 'kita' dan 'mereka', yang mengacu pada kelompok mereka sendiri dan kelompok tertentu di luar mereka, adalah tanda tidak terjadinya pergeseran bahasa. Bahasa biasanya pusat konsep 'kita-mereka.'

Seperti yang sudah dipaparkan sebelumnya, tahap awal yang menyebabkan adanya pergeseran bahasa adalah bilingualisme atau multilingualisme, meskipun banyak komunitas bilingual yang kondisinya tetap stabil. Mungkin tanda awal 
pergeseran adalah pergerakan satu bahasa baru ke ranah-ranah tertentu yang sebelumnya ditempati oleh bahasa lama.

Lebih luas lagi, terdapat kondisi sosioekonomi dalam skala besar yang menyebabkan pergeseran bahasa, meskipun tidak menjamin. Kelompok penutur yang tinggal di perkotaan, pusat-pusat industri atau komersial, jika mereka berbicara dengan bahasa yang berbeda dengan kelompok lain yang lebih besar, cenderung akan bergeser dan lebih memilih menggunakan bahasa lain yang dipakai oleh kelompok yang lebih besar. Sebaliknya, kelompok penutur yang hidup di wilayah geografis yang terisolasi atau yang berkecimpung dalam pertanian, cenderung lebih mempertahankan bahasa minoritas. Hampir semua kasus pergeseran bahasa dalam masyarakat terjadi melalui peralihan intergenerasi. Dengan kata lain, peralihan bahasa terjadi melalui beberapa generasi dalam satu masyarakat bilingual dalam jangka waktu yang cukup panjang.

Menurut para ahli bahasa, selain bilingualisme terdapat beberapa faktor lain yang menjadi pemicu pergeseran bahasa. Faktor-faktor tersebut antara lain migrasi, baik yang dilakukan oleh kelompok kecil ke suatu wilayah yang menyebabkan bahasa mereka tidak lagi digunakan, maupun oleh kelompok besar yang memperkenalkan populasi lokal dengan bahasa baru.

\section{METODE PENELITIAN}

Penelitian ini dilakukan dengan menggunakan metode kualitatif. Rancangan yang digunakan adalah sosiolinguistik dengan menggunakan teori pergeseran dan pemertahanan bahasa dari Fasold (1984). Penelitian ini dilakukan dengan melakukan observasi ke lapangan secara langsung dengan teknik pengumpulan data melalui pengamatan dan pencatatan konteks suatu percakapan, merekam tuturan, dan wawancara. Setelah data tersebut terkumpul kemudian peneliti mentranskripsikan data, lalu mengklasifikasi data berdasarkan ranahnya.
Setelah diklasifikasi peneliti melakukan analisis dengan menggunakan teori di atas dengan tujuan mencari gejala-gejala kebahasaan yang dapat menjadi indikator pergeseran atau pemertahanan bahasa, serta mencari faktor-faktor yang menyebabkan terjadinya pergeseran atau pemertahanan bahasa.

\section{DATA DAN PEMBAHASAN}

\section{A. Deskripsi Data}

Dalam penelitian ini, peneliti mengumpulkan data yang berupa konteks dan tuturan atau percakapan di sekitar wilayah Pangandaran. Pengumpulan data ini dilakukan melalui teknik wawancara dan pengamatan. Peneliti menyadari sepenuhnya bahwa data yang terkumpul dan dianalisis tidak cukup mewakili untuk penelitian yang mengkaji bagaimana dinamika pemakaian bahasa dalam suatu masyarakat tutur hingga akhirnya dapat dilihat apakah fenomena yang ada menunjukkan pergerakan ke arah pergeseran bahasa atau pemertahanan bahasa. Hal ini disebabkan oleh segala keterbatasan yang peneliti alami. Namun, laporan penelitian ini diharapkan mampu memberikan suatu gambaran untuk melihat situasi kebahasaan di wilayah Pangandaran dan menjadi dasar hipotesis bagi penelitian lain dengan penelitian yang lebih besar.

\section{Ranah Keluarga \\ Data 1}

Bahasa : Sunda

Situasi : Informal

Paritisipan : Ayah (Sutikno, 34 tahun), Ibu (Lilis, 25 tahun), dan anak (Imam, 5 tahun).

Percakapan :

Imam (anak)

bagi artos atuh"

Lilis (ibu)

: "Ma, hayang jajan,

kaditu!!"

Imam (anak)

sieun ngambek"

Lilis (ibu)

: "Menta ka Bapa

arep jajan" 
Sutikno (ayah) : "Mau wis jajan tho, mengko sore wae sekalian Mama belonjo ning pasar"

Dari data pertama diperoleh keterangan bahwa pasangan suami istri dalalm keluarga tersebut berasal dari etnis yang berbeda. Suaminya, yang berprofesi sebagai nelayan, beretnis Jawa (Magelang), sedangkan istrinya, yang berprofesi sebagai pedagang, beretnis Sunda (Ciamis). Jadi keluarga tersebut dibentuk dari kawin campur. Namun, bahasa pertama yang diajarkan pada anaknya bukanlah bahasa nasional melainkan bahasa ibunya, yaitu bahasa Sunda. Pasangan tersebut adalah multilingual. Mereka dapat berbicara dengan menggunakan bahasa Sunda, Jawa, dan Indonesia. Komunikasi antara suami dan istri dilakukan dengan menggunakan dua bahasa yaitu bahasa Sunda dan Jawa.

\section{Data 2}

Bahasa : Sunda

Situasi : Informal

Partisipan : Ayah (Adang, 40 tahun), Ibu (Anah, 37 tahun) dan dua orang anak.

Percakapan :

Adang (ayah) : "Ma, ari ayakan paranti moe lauk dimana?"

Anah (ibu) : "Tanyakeun ka si Aa, kamari teh nu terakhir make si Aa"

Aa (anak ke-1) : "Tuh di tukangeun panto dapur"

Eneng (anak ke-2) : "Tos dialihkeun $k u$ Eneng ka kamar mandi da sieun aya nu maok"

Keluarga ini dibentuk dari pasangan yang berasal dari etnis yang sama, yaitu Sunda. Suaminya berprofesi sebagai nelayan dan istrinya sebagai ibu rumah tangga. Kedua anak dalam keluarga itu berbahasa ibu bahasa Sunda sehingga komunikasi dalam keluarga dilakukan dengan menggunakan bahasa Sunda. Pasangan dalam keluarga tersebut dapat menguasai bahasa Sunda, Jawa, dan Indonesia.

\section{Ranah Pendidikan}

\section{Data 3}

Tempat : Halaman SD Negeri 5 Pangandaran

Partisipan : Tiga orang siswa kelas 5

Situasi : Informal

Percakapan :

Siswa 1: "Wah teu nyangka pisan maneh alus peunteuna, padahal eusina ampir kabeh dibejaan ti si Rian"

Siswa 2 : "Eh pan kumaha amal-amalan atuh eta mah, hehe..."

Siswa 3 : "Dasar maneh mah sok gede milik wae. Engke deui mah moal dibejaan ah, rugi Bandar, hahahaha..."

Siswa 1 : "Berarti bener ceuk kolot, tong sok ngabejaan batur matak bodo ceunah"

Siswa 2 : "Ah ceuk nu sirik eta mah!!"

Berdasarkan hasil pengamatan di sekitar Sekolah Dasar Negeri 5 Pangandaran, peneliti mengamati bahasa yang dipakai sesama siswa yang sedang beristirahat menggunakan bahasa Sunda. Topik yang dibicarakan adalah nilai hasil ulangan harian mereka. Ketika peneliti hampiri dan bertanya dengan menggunakan bahasa Indonesia, mereka pun merespon dengan menggunakan bahasa Indonesia. Setelah kami bercakap-cakap, maka diperoleh keterangan bahwa bahasa pengantar di dalam kelas adalah bahasa Indonesia dan ketiga siswa tersebut sudah duduk di kelas 5.

\section{Data 4}

Bahasa : Sunda

Tempat : Warung di pinggir pantai

Partisipan

- penjaga warung (statusnya masih pelajar kelas 2 SMA)

- peneliti

Situasi : Informal 
Percakapan :

Penjaga Warung : "Mangga, Teh, mau beli apa?"

Peneliti

: "Bakso ya sama es teh manisnya satu"

Penjaga Warung Peneliti : "Mangga, Teh" : "Ade rajin ya, masih kecil sudah buka usaha"

Penjaga Warung: "Sebenarnya saya masih sekolah kelas 2 SMA, Teh. Tapi biasanya setelah pulang sekolah bantuin Mamah jagain warung."

Peneliti: "Waaah, kalau begitu justru itu lebih dari rajin. Jarang-jarang loh anak seumuran Ade yang mau bantuin orangtua, hehehe...."

Penjaga Warung : "Ah, Teteh bisa aja. Hatur nuhun."

Data ini diperoleh melalui hasil wawancara dengan seorang siswi Sekolah Menengah Atas Negeri 1 Pangandaran. Dari siswi tersebut peneliti memeroleh informasi bahwa bahasa yang digunakan dalam aktifitas belajar mengajar adalah bahasa Indonesia, kecuali untuk mata pelajaran Bahasa Daerah, bahasa yang dipakai adalah bahasa Sunda. Kemudian bahasa yang dipakai untuk berkomunikasi sesama siswa di sekolah adalah lebih sering menggunakan bahasa Sunda. Responden yang peneliti wawancarai ternyata tidak bisa berbahasa Jawa, dia hanya menguasai bahasa Sunda (bahasa ibunya) dan bahasa Indonesia.

\section{Ranah Pemerintahan}

\section{Data 5}

Bahasa : Bahasa Sunda

Tempat : Kantor Kepala Desa Pangandaran

Partisipan :

- Sugi (Sekdes, 37 tahun)

- Peneliti
Percakapan

- Sugianto (Kaur, 30 tahun)

Peneliti : "Permisi, Pak, maaf mengganggu"

Sekdes : "Oh, ya, silakan, Mbak. Ada yang bisa saya bantu?'

Peneliti : "Saya mau minta izin untuk melakukan penelitian di sekitar wilayah Desa ini, Pak"

Sekdes : "Penelitian tentang apa ya?"

Peneliti : "Tentang situasi kebahasaannya, Pak"

Sekdes: “Oh, ya, silakan, Mbak. Barangkali nanti perlu sesuatu, ada staf saya yang bisa membantu, ya. Pak Kaur, pai weruh si Mbak'e ana apa-apa, tolong dibantu bae, ya!"

Kaur : "Nggih, Pak"

Peneliti : "Terima kasih banyak, Pak"

Sekdes : "Sama-sama, Mbak"

Dalam ranah pemerintahan ini diperoleh informasi bahwa bahasa secara tertulis, dalam situasi formal, baik dalam bentuk surat menyurat maupun pengumuman digunakan bahasa nasional yaitu bahasa Indonesia. Kemudian, dalam rapat, bahasa yang digunakan seringkali campur bukan hanya menggunakan bahasa Indonesia tetapi juga bahasa Sunda. Dalam kegiatan sehari-hari dalam melayani masyarakat, bahasa yang digunakan adalah bahasa Sunda kecuali jika tamu yang datang menjawab dengan bahasa Jawa, maka akan dilayani dengan menggunakan bahasa Jawa.

Jadi, para aparat desa di kantor tersebut adalah multilingual, mereka menguasai bahasa Sunda, Jawa, dan Indonesia. Bahkan Kepala Desa-nya dapat berkomunikasi dengan menggunakan bahasa Inggris, karena beliau memiliki pekerjaan sampingan sebagai pemandu wisata di Pangandaran dan juga sebagai guru Bahasa Inggris di tempat kursus Bahasa Inggris untuk anak-anak.

\section{Ranah Perdagangan}

\section{Data 6}

Tempat : Tepi pantai Pangandaran 
Partisipan : Tukang sewa perahu dan pengunjung

Situasi : Informal

Bahasa : bahasa Sunda dan bahasa

Indonesia

Percakapan :

Tukang sewa : "Tos paling mirah iyeu teh, margi ka sapuluh lokasi, mangga. Iyeu teh anu paket janten langkung mirah pisan jaba tiasa ditaekan $k u$ sapuluh jalmi. Mangga teu langkung bade nyandak numana."

Pengunjung : "Sabaraha kitu mirah teh?" Tukang sewa: "Biasana mah anu paket keliling sapuluh lokasi tilu ratus lima puluh tapi wioslah ayeuna mah janten dua ratus lima puluh, mangga. Mun bade ka Pasir Putih wungkul sapuluh rebuJadi itu udah dipesen ama tiket, Pa. Kalau kita jalan kaki tiketnya kan sebelas ribu lima ratus. Lagian kita liat taman laut yang satu meter ke bawah. Gak basah, gak. Dijamin gak basah kalau naek perahu, gak basah. Meungpeung lagi bagus ombakna."

Pengunjung : "Ah, si Bapa mah paling bisa ngerayuna teh"

Dari data di atas dapat dilihat bahwa tukang sewa perahu dan pengunjung adalah bilingual. Mereka menguasai dua bahasa, yaitu bahasa Sunda dan bahasa Indonesia. Dalam memberikan penawaran pada pengunjung pantai pada awalnya tukang sewa perahu menggunakan bahasa Sunda, tetapi kemudian beralih menggunakan bahasa Indonesia. Bahasa Indonesia yang dipakainya bukanlah bahasa Indonesia standar melainkan bahasa Indonesia informal, bahkan kemudian muncul interferensi bahasa Sunda, seperti munculnya kata meungpeung dan naek di tengah-tengah tuturan dalam bahasa Indonesia. Oleh karena itu, dapat disimpulkan bahwa dalam data ini terjadi campur kode, yaitu dengan adanya penggunaan bahasa Indonesia yang dicampur dengan serpihan-serpihan bahasa Sunda.

\section{Data 7}

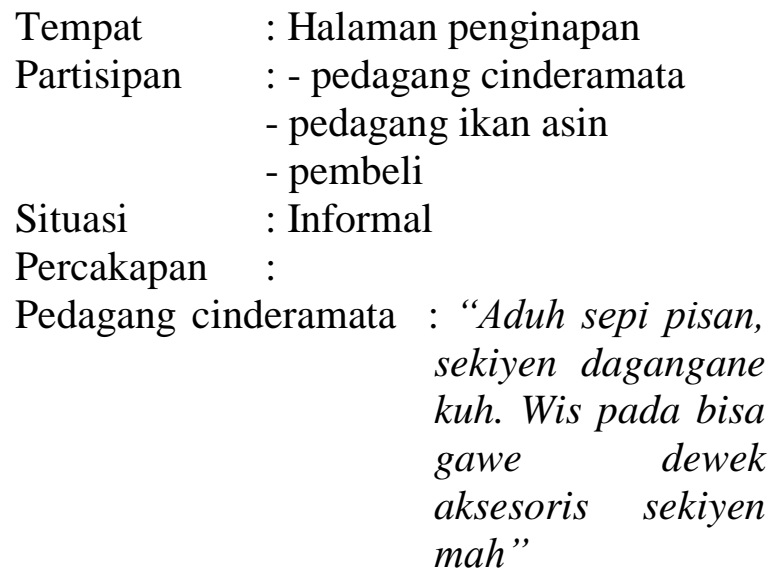

Pedagang ikan asin : "Alhamdulillah yen iwak asin masih akeh sing tuku. Bokat pada males gawe dewek, wis lawas, angel, mambu maning"

Pedagang cinderamata

: "Heиeuh
bener, masa
kudur ngalih
dadi dagangan
iwak asin"

Pedagang ikan asin : "Eh, aja sih. Engko tambah akeh saingane kita!'”

Kedua pedagang : "Hehehehe....."

Pembeli : "Bu....."

Pedagang ikan asin : "Eh, mangga neng dipilih-pilih, seueur macemna da. Upami nu iyeu mah, asin jambal roti. Tos enak teh mirah jaba awet dicandak perjalanan jauh ge"

Pedagang cinderamata :"Sakantenan neng sareng aksesorisna kanggo oleh-oleh 
Pembeli

Kedua pedagang

Percakapan yang dilakukan oleh sesama pedagang, yakni seorang pedagang cinderamata dan seorang pedagang ikan asin, dilakukan dalam bahasa Jawa. Namun, ketika seorang pembeli menghampiri mereka, bahasa yang dipakai oleh kedua pedagang tersebut beralih ke dalam bahasa Sunda ketika menawarkan dagangannya. Dari sini, dapat dilihat bahwa para partisipan dalam percakapan tersebut adalah bilingual. Mereka menguasai dua bahasa, yaitu bahasa Sunda dan Jawa, dengan baik. Dengan adanya peralihan bahasa, ini juga menunjukkan adanya satu peristiwa kebahasaan yang disebut dengan alih kode. Hal ini terbukti dengan adanya peralihan bahasa ketika berganti topik pembicaraan atau dapat dikatakan berganti ranah dari ranah pertemanan ke ranah perdagangan atau lebih tepatnya transaksi.

\section{B. Hasil Analisis dan Pembahasan}

Berdasarkan deskripsi ketujuh data di atas yang telah diklasifikasi ke dalam empat ranah: keluarga, pendidikan, pemerintahan, dan perdagangan, dapat diperoleh gambaran mengenai dinamika pemakaian bahasa di wilayah Pangandaran. Bahasa yang dominan dipakai di wilayah Pangandaran adalah bahasa Indonesia, Jawa, dan Sunda. Dalam ranah-ranah formal seperti aktifitas di kelas (pendidikan) dan aktifitas di kantor kepala desa (rapat dan surat-menyurat) bahasa yang digunakan adalah bahasa Indonesia.

Bahasa Jawa, digunakan oleh sesama penutur etnis Jawa di Pangandaran dalam situasi informal dalam ranah perdagangan. Yaitu, di sela-sela aktifitas perdagangan para penutur beretnis Jawa berkomunikasi dengan bahasa Jawa. Namun, bahasa Jawa tidak hanya dituturkan oleh penutur beretnis
Jawa, tetapi juga oleh etnis Sunda. Seperti dalam data di atas, seorang perempuan beretnis Sunda yang melakukan kawin campur dengan lelaki beretnis Jawa seringkali berkomunikasi dengan bahasa Jawa.

Berdasarkan data yang diperoleh dapat pula dikatakan bahwa bahasa yang paling banyak dipakai oleh masyarakat di Pangandaran adalah bahasa Sunda. Hal ini terbukti bahwa bahasa Sunda dipakai di semua ranah (keluarga, pendidikan, pemerintahan, maupun perdagangan). Selain itu, bahasa Sunda tidak hanya dipakai dalam situasi informal tetapi juga formal, contohnya dalam kegiatan pengajaran Bahasa Daerah di dalam kelas.

Dari data-data yang diperoleh, terdapat pemilihan bahasa (langauge choice) seperti yang dikemukakan oleh Fasold (1984). Pemilihan bahasa tersebut terjadi melalui:

1. Alih kode (code switching): secara umum perbedaan penggunaan bahasa dalam ranah yang berbeda merupakan bentuk dari alih kode. Akan tetapi, terjadi pula alih kode dalam peristiwa tutur yang dilakukan dalam lokasi. Alih kode dalam lokasi yang sama karena penutur berbicara pada dua kelompok mitra tutur yang berbeda. Yaitu ketika penutur berbicara pada sesama pedagang, penutur menggunakan bahasa Jawa, tetapi kemudian beralih ke dalam bahasa Sunda, ketika penutur menawarkan barang dagangannya kepada pembeli yang menghampirinya.

2. Campur kode (code mixing): peristiwa ini terjadi dalam ranah perdagangan ketika tukang sewa perahu menawarkan jasanya. Pada awalnya menawarkan dengan bahasa Sunda, tetapi kemudian beralih ke bahasa Indonesia yang dicampur dengan beberapa kosa kata dalam bahasa Sunda.

Berdasarkan situasi pemakaian bahasa di wilayah Pangandaran, dapat dikatakan bahwa gejala kebahasaaan yang terjadi di sana lebih cenderung menunjukkan adanya pemertahanan bahasa dalam 
komunitas multilingual daripada pergeseran bahasa. Hal ini terlihat dari beberapa aspek seperti yang dikemukkan oleh Fasold (1984), pemertahanan bahasa terjadi juga dalam komunitas multilingual. Yakni ketika terjadi gejala yang menunjukkan adanya penggunaan bahasa yang berbeda untuk ranah yang berbeda. Di wilayah Pangandaran, terdapat beberapa penggunaan bahasa yang berbeda untuk ranah yang berbeda. Misalnya bahasa Indonesia yang cenderung digunakan untuk situasi formal sedangkan bahasa Sunda dan Jawa digunakan dalam situasi yang informal.

Dalam ranah keluarga, seorang ibu masih mengajarkan bahasa ibu sebagai bahasa pertama mereka. Misalnya, dalam keluarga Sunda, bahasa ibu yang digunakan adalah bahasa Sunda. Betapa kuatnya bahasa Sunda, terlihat pula ketika terjadi kawin campur dengan ibu beretnis Sunda dan ayah beretnis Jawa, bahasa pertama yang diperkenalkan pada anaknya pun tetap bahasa Sunda. Tidak terjadinya perbedaan penggunaan bahasa antara generasi tua dan generasi muda. Hal ini terjadi karena di dalam ranah keluarga bahasa pertama yang diperkenalkan masih bahasa ibu atau bahasa daerah.

Berdasarkan paparan di atas jelas tidak terjadi gejala kompetisi bahasa yang mengarah pada pergeseran bahasa karena setiap bahasa digunakan secara harmonis dalam ranah-ranah yang berbeda.

\section{SIMPULAN}

Dari hasil analisis dan pembahasan terdapat beberapa simpulan yang dapat dirumuskan seperti berikut:

1. Masyarakat Pangandaran adalah komunitas multilingual yang dominan menguasai tiga bahasa yaitu bahasa Sunda, Jawa, dan Indonesia. Ada juga beberapa orang yang menguasai bahasa Inggris karena tuntutan pekerjaan dan terbiasa berinteraksi dengan wisatawan dari luar negeri.
2. Bahasa Sunda digunakan di semua ranah yang peneliti observasi, yakni ranah keluarga, pendidikan, pemerintahan, dan perdagangan. Sementara itu, bahasa Indonesia cenderung digunakan dalam ranah formal seperti aktifitas pemerintahan dan pendidikan, sedangkan bahasa Jawa digunakan dalam ranah perdagangan dan keluarga atau pertemanan.

3. Peristiwa kebahasaan yang terjadi di wilayah Pangandaran adalah alih kode (code switching) dan campur kode (code mixing). Peristiwa ini terjadi sebagai bentuk adanya pemilihan bahasa (language choice).

4. Situasi pemakaian bahasa di wilayah Pangandaran tidak menunjukkan adanya pergeseran bahasa, justru gejala yang ada lebih cenderung ke arah pemertahanan bahasa dalam komunitas multilingual.

Berdasarkan beberapa simpulan di atas maka dapat dikatakan bahwa situasi multilingualisme di wilayah Pangandaran relatif stabil karena tidak menunjukkan adanya kompetisi antarbahasa.

\section{DAFTAR PUSTAKA}

Chaer, A. \& Agustina, L. 1995. Sosiolinguistik Perkenalan Awal. Jakarta: Rineka Cipta.

Fasold, Ralph. 1984. The Sociolinguistics of Society. England: Basil Blackwell Publisher.

Hendayana, Yayat. 12 Januari 2008. Upaya Pemeliharaan Bahasa Daerah. Kompas, 14 November 2007. Bahasa Daerah Terancam Punah.

Rusyana, Yus. 1999. Fungsi Bahasa Daerah $\begin{array}{lrr}\text { dalam } & \text { Kehidupan } & \text { Manusia } \\ \text { Indonesia: } & \text { Keadaan } & \text { Menjelang } \\ \text { Milenium } & \text { Ketiga. } & \text { Makalah } \\ \text { disampaikan } & \text { di } & \text { Konferensi } \\ \text { Bahasa Nusantara. } & \end{array}$ 